\title{
Clinical characteristic of 100 patients from pilot registry of heart failure patients hospitalized in the district hospital in Poland
}

\author{
Charakterystyka kliniczna 100 pacjentów pilotażowego rejestru chorych \\ z niewydolnością serca hospitalizowanych w szpitalu powiatowym w Polsce
}

\author{
Anna Praska-Ogińska, Janusz Bednarski \\ Department of Cardiology, John Paul II Western Hospital in Grodzisk Mazowiecki, Poland
}

\section{Abstract}

Introduction. Nowadays heart failure (HF) presents an enormous and rapidly growing public health problem. HF is characterized by high morbidity and mortality and high costs.

Material and methods. The analysis included medical records of 100 consecutive patients with HF treated in the Department of Cardiology during the first quarter of 2015.

Results. The mean age of the whole investigated population was 73 years ( $63 \%$ males). The most prevalent concomitant diseases were: arterial hypertension (58\%), coronary artery disease (46\%), the presence of moderate or severe mitral or aortic valvular defect (34\%), atrial fibrillation (38\%), and diabetes mellitus (29\%).

Conclusions. Data from hospitalized HF registries are useful to better understand the clinical characteristics, patient management and outcomes after discharge.

Key words: heart failure, hospitalization, registry

Folia Cardiologica 2017; 12, 4: 337-341

\section{Introduction}

Heart failure (HF) is a major public health problem. It is estimated that the prevalence of $\mathrm{HF}$ is $1-2 \%$ in the general population and as high as $10 \%$ in patients over 70 years of age [1]. Rapid increase in the number of patients with $\mathrm{HF}$ is a consequence of both the aging of society and the development of interventional cardiology and electrotherapy. Currently, the most common causes of HF are ischemic heart disease and hypertension. HF is associated with very poor prognosis and 5-year survival rates are worse than for most cancers [2].
The aim of this study was to present the clinical profile of patients hospitalized for heart failure in the cardiology department of a multi-specialty district hospital in Poland.

\section{Material and methods}

Medical records of 10,925 patients hospitalized at the Western Hospital in Grodzisk Mazowiecki, Poland in the first quarter of 2015 were analyzed retrospectively. Of this group, the authors selected medical records of 100 consecutive patients hospitalized in the cardiology department in whom HF was indicated in the hospital discharge summary as a primary diagnosis. 


\section{Clinical characteristics of patients}

Among the selected patients, the median age was 73 years. In this population, males accounted for $63 \%$ of the patients, were younger and had lower comorbidity burden compared with hospitalized women. Nearly one third of the patients were admitted in an urgent mode based on the decision by the Emergency Medical Service team; $64 \%$ of the patients reported the New York Heart Association (NYHA) class III or IV symptoms at admission. The most common concomitant disease was hypertension, which affected $64 \%$ of the patients. Supraventricular arrhythmias, i.e. atrial fibrillation or flutter, occurred in $38 \%$ of the patients, and $46 \%$ had coronary artery disease. The most common valvular heart defect was mitral regurgitation, which was almost 6 times more frequent than aortic stenosis (mild valvular heart defects in echocardiographic evaluation were disregarded). Mean levels of $\mathrm{N}$-terminal B-type natriuretic propeptide (NT-proBNP) and sodium were $4819 \pm 6968 \mathrm{pg} / \mathrm{mL}$ and $138 \pm 4 \mathrm{mmol} / \mathrm{L}$, accordingly. Most patients had impaired renal function, defined as glomerular filtration rate (GFR) less than $50 \mathrm{~mL} / \mathrm{min} / 1.73 \mathrm{~m}^{2}$, and $17 \%$ had stage $4 / 5$ chronic renal disease. Thirty-one percent of the patients had left ventricular ejection fraction (LVEF) $\geq 50 \%$. Forty-two percent of the patients had left ventricular systolic dysfunction of various degrees, of which $2 / 3$ had an LVEF less than $40 \%$. Twenty-eight percent of the patients did not undergo echocardiographic evaluation of LVEF during hospitalization (Table 1).

\section{Discussion}

It is estimated that the number of patients with HF in Poland is 600-700 thousand and that every fifth person will develop HF at some point of his/her life [2]. Medical care for patients with HF both in outpatient setting and during frequent hospitalizations due to HF exacerbation, which are typical of the natural course of the disease, cause considerable social and financial burden.

Our analysis included patients hospitalized in the cardiology department of a multi-specialty district hospital, where there is also a department of internal diseases. The decision about the destination of the patient (a department of cardiology vs. department of internal diseases) is taken during his/her stay at the Hospital Emergency Department, usually after prior cardiac consultation. This allows for identification of patients who require specialist treatment (Table 2).

The mean age of patients hospitalized due to HF in Poland is consistent with the age of patients participating in large registry trials in developed countries such as Japan (ATTEND) [3], France (EFICA) [4] or USA (ADHERE [5], OPTIMIZE-HF [6]).
Table 1. Clinical characteristics of patients

\begin{tabular}{|c|c|}
\hline Parameter & Value \\
\hline Age & 73 years \\
\hline Male & $63 \%$ \\
\hline \multicolumn{2}{|l|}{ Mode of admission to hospital: } \\
\hline - arrival by ambulance & $28 \%$ \\
\hline - own or public transport & $72 \%$ \\
\hline Symptoms in III/IV NYHA class & $68 \%$ \\
\hline Hypertension & $58 \%$ \\
\hline History of myocardial infarction & $24 \%$ \\
\hline $\mathrm{PCl}$ & $18 \%$ \\
\hline CABG & $4 \%$ \\
\hline AF/AFL & $38 \%$ \\
\hline Mitral insufficiency & $29 \%$ \\
\hline Aortal stenosis & $5 \%$ \\
\hline COPD & $16 \%$ \\
\hline Type 2 diabetes & $29 \%$ \\
\hline Pacemaker & $2 \%$ \\
\hline$I C D$ & $7 \%$ \\
\hline CRT & $3 \%$ \\
\hline Stroke/TIA & $7 \%$ \\
\hline \multicolumn{2}{|l|}{ BMI $\left[\mathrm{kg} / \mathrm{m}^{2}\right]$ : } \\
\hline - $\quad<18.5$ & $20 \%$ \\
\hline - $18.5-24.99$ & $10 \%$ \\
\hline - $\quad 25-29.99$ & $33 \%$ \\
\hline - $\quad \geq 30$ & $35 \%$ \\
\hline NT-proBNP [pg/mL] & 4819 \\
\hline $\mathrm{Hb}[\mathrm{g} / \mathrm{dL}]$ & 12.79 \\
\hline $\mathrm{Na}[\mathrm{mmol} / \mathrm{L}]$ & 137.7 \\
\hline \multicolumn{2}{|l|}{ GFR $\left[\mathrm{mL} / \mathrm{min} / 1.73 \mathrm{~m}^{2}\right]:$} \\
\hline - $<30$ & $17 \%$ \\
\hline - $30-49$ & $71 \%$ \\
\hline - $>50$ & $12 \%$ \\
\hline \multicolumn{2}{|l|}{ LVEF: } \\
\hline - $<40 \%$ & $27 \%$ \\
\hline - $40-49 \%$ & $15 \%$ \\
\hline - $\quad \geq 50 \%$ & $31 \%$ \\
\hline \multicolumn{2}{|c|}{$\begin{array}{l}\text { NYHA - New York Heart Association; PCI - percutaneous coronary intervention; CABG - coronary } \\
\text { artery bypass grafting; AF - atrial fibrillation; AFL - atrial flutter, COPD - chronic obstructive } \\
\text { pulmonary disease; ICD - implantable cardioverter-defibrillator; CRT - cardiac resynchronization } \\
\text { therapy; TIA - transient ischemic attack; BMI - body mass index; NT-proBNP - N-terminal B-type } \\
\text { natriuretic propeptide; Hb - hemoglobin; Na - sodium; GFR - glomerular filtration rate; LVEF - left } \\
\text { ventricular ejection fraction }\end{array}$} \\
\hline
\end{tabular}




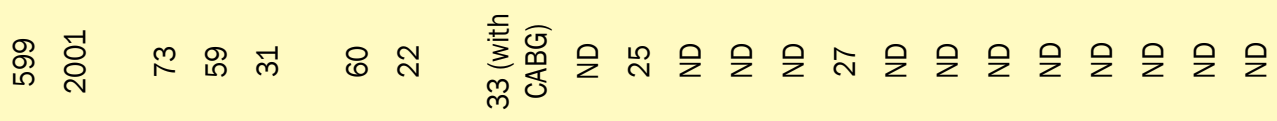

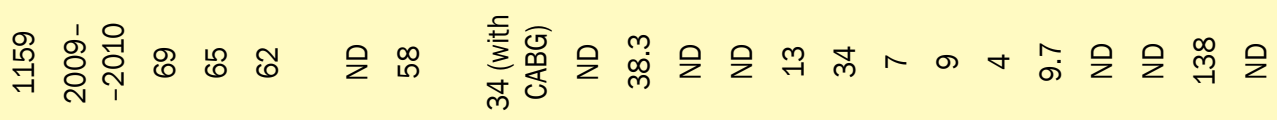

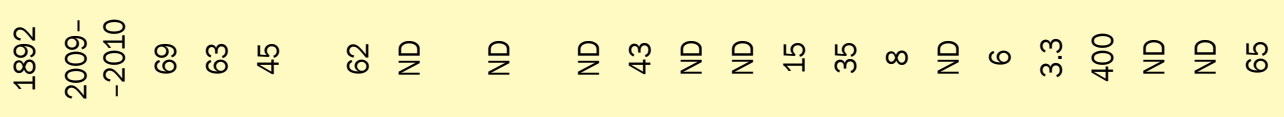

总 岀

寻宲㞼

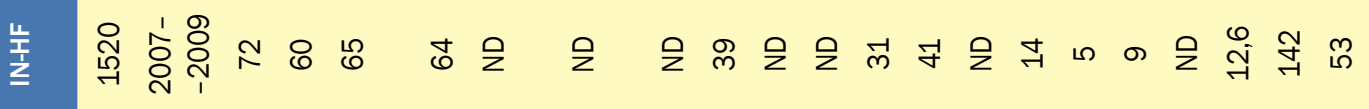

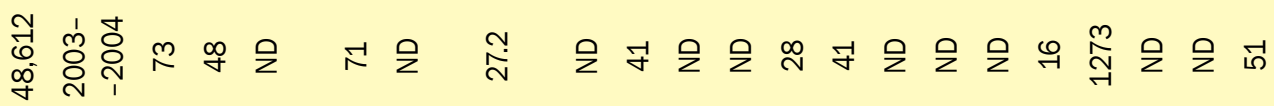

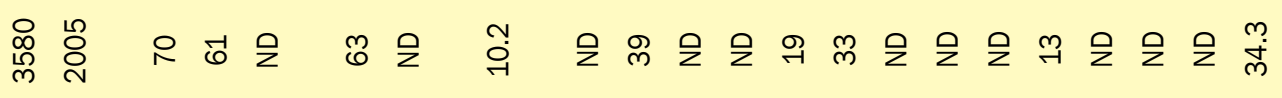

$\infty$
0
0
0
0

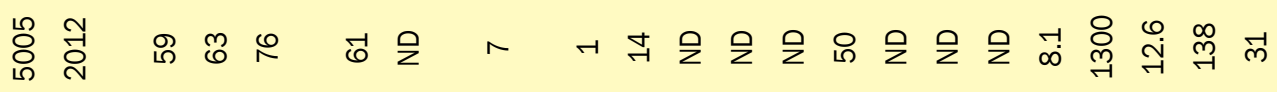

유 뮨 
As in most European registries, such as ESC-HF Pilot [7], EHFS II [8], IN-HF [9], also in our study the majority of hospitalized patients $(63 \%)$ were males. Women are traditionally less represented, not only in randomized clinical trials on HF but also in hospital registries. There is, however, one exception - available data indicate higher proportion of women requiring hospitalization due to HF only in the United States, which is contrary not only to data obtained in Europe but also in other regions of the world.

It is also worth noting that, as shown in the Western Hospital registry, women at the time of diagnosis of HF were older than men and were more likely to have heart failure with preserved ejection fraction (HFpEF).

The lower prevalence of coronary heart disease observed in our study (46\% vs $50-57 \%$ in other registries) may be due to a slightly different questionnaire developed to describe a population in which coronary artery disease was diagnosed solely based on a history of myocardial infarction, prior coronary revascularization or coronary angiography. However, when taking into account the proportion of patients with HF and a history of myocardial infarction, the differences are much lower $-24 \%$ vs. $22 \%$ in the French registry or $31 \%$ in the US registry.

The prevalence of hypertension at $58 \%$ is similar to data from all European registries. The exception is again American population, where hypertension is present in about $75 \%$ of people. This is obviously related to a higher prevalence of obesity in US society compared to Western Europe or Poland.

A similar pattern is observed regarding the prevalence of type 2 diabetes. Its frequency, due to the epidemic of obesity, is markedly higher in the US (40$-44 \%)$ compared with the Polish population presented in our study (29\%) or the French registry (27\%). As showed by all registries, atrial fibrillation affects about $38-40 \%$ of patients hospitalized due to HF and is, along with hypertension, the major comorbid condition accompanying HFpEF.
It is also worth noting that the proportion of HFpEF patients hospitalized in recent years has gradually increased. Since many hospital records do not show LVEF values, we still do not have reliable epidemiological data on the actual HfrEF/HFpEF ratio. It seems, however, that this percentage can reach as much as $60-65 \%$ of hospitalized patients, which is also confirmed by the presented registry.

Data concerning the occurrence of comorbid conditions, such as chronic kidney disease (CKD) or chronic obstructive pulmonary disease (COPD), are also comparable between various $\mathrm{HF}$ registries. For example, the prevalence of CKD with GFR $<30 \mathrm{~mL} / \mathrm{min} / 1.73 \mathrm{~m}^{2}$ is $17 \%$ in the presented registry vs $20 \%$ in global registries [12]. The prevalence of COPD (16\%) is consistent with both OPTIMIZE-HF (15\%) [6] and European EHFS II (19\%) [8].

\section{Conclusions}

New registry trials have been emerging over recent years. The data collected in these databases provide an excellent source of information both for the medical professionals and for healthcare system managers. Cardiovascular societies continuously update the guidelines for the diagnosis and treatment of HF - both considering the results of clinical trials, in which the patient population is selected and unrealistic due to strict criteria for inclusion and exclusion, and analyzing clinical practice based on registry data. The study presented above proves that the clinical profile of Polish patients is very similar to that of patients in developed countries. For a practitioner, this means that recommendations in the guidelines of the European Society of Cardiology can and should be directly implemented in the treatment of Polish patients.

\section{Conflict of interest(s)}

None declared.

\section{Streszczenie}

Wstęp. Niewydolność serca (HF) stanowi poważny problem współczesnej medycyny. Choroba charakteryzuje się wysoką śmiertelnością, a rosnąca liczba chorych pociąga za sobą wysokie koszty ochrony zdrowia.

Materiał i metody. W niniejszej pracy oceniono profil kliniczny 100 pacjentów hospitalizowanych w pierwszym kwartale 2015 roku na oddziale kardiologicznym szpitala powiatowego.

Wyniki. Średni wiek chorych wynosił 73 lata (63\% mężczyzn). Najczęstszymi chorobami towarzyszącymi były: nadciśnienie tętnicze (58\%), choroba wieńcowa (46\%), umiarkowana wada mitralna lub aortalna (34\%), migotanie przedsionków (38\%), cukrzyca (29\%).

Wnioski. Dane z rejestrów są pomocne zarówno dla środowiska lekarskiego, jak i zarządzających służbą zdrowia.

Słowa kluczowe: niewydolność serca, hospitalizacja, rejestr

Folia Cardiologica 2017; 12, 4: 337-341 


\section{References}

1. Ponikowski P, Voors A, Anker S, et al. Wytyczne ESC dotyczące diagnostyki i leczenia ostrej i przewlekłej niewydolności serca w 2016 roku. Kardiol Pol. 2016; 74(10): 1037-1147, doi: 10.5603/kp.2016.0141.

2. Sekcja Niewydolności Serca PTK. Niewydolność serca w Polsce-raport 2016. http://www.niewydolnosc-serca.pl/barometr.pdf (20.01.2017).

3. Sato N, Kajimoto K, Asai K, et al. ATTEND Investigators. Acute decompensated heart failure syndromes (ATTEND) registry. A prospective observational multicenter cohort study: rationale, design, and preliminary data. Am Heart J. 2010; 159(6): 949-955.e1, doi: 10.1016/j. ahj.2010.03.019, indexed in Pubmed: 20569705.

4. Zannad F, Mebazaa A, Juillière Y, et al. EFICA Investigators. Clinical profile, contemporary management and one-year mortality in patients with severe acute heart failure syndromes: The EFICA study. Eur J Heart Fail. 2006; 8(7): 697-705, doi: 10.1016/j.ejheart.2006.01.001, indexed in Pubmed: 16516552.

5. Fonarow GC, Heywood JT, Heidenreich PA, et al. ADHERE Scientific Advisory Committee and Investigators. Temporal trends in clinical characteristics, treatments, and outcomes for heart failure hospitalizations, 2002 to 2004: findings from Acute Decompensated Heart Failure National Registry (ADHERE). Am Heart J. 2007; 153(6): 1021-1028, doi: 10.1016/j.ahj.2007.03.012, indexed in Pubmed: 17540205.

6. Gheorghiade M, Abraham WT, Albert NM, et al. OPTIMIZE-HF Investigators and Coordinators. Systolic blood pressure at admission, clinical characteristics, and outcomes in patients hospitalized with acute heart failure. JAMA. 2006; 296(18): 2217-2226, doi: 10.1001/ /jama.296.18.2217, indexed in Pubmed: 17090768.

7. Balsam P, Tymińska A, Kapłon-Cieślicka A, et al. Predictors of oneyear outcome in patients hospitalised for heart failure: results from the Polish part of the Heart Failure Pilot Survey of the European Society of Cardiology. Kardiol Pol. 2016; 74(1): 9-17, doi: 10.5603/ /KP.a2015.0112, indexed in Pubmed: 26101021.

8. Nieminen MS, Brutsaert D, Dickstein K, et al. EuroHeart Survey Investigators, Heart Failure Association, European Society of Cardiology. EuroHeart Failure Survey II (EHFS II): a survey on hospitalized acute heart failure patients: description of population. Eur Heart J. 2006; 27(22): 2725-2736, doi: 10.1093/eurheartj/ehl193, indexed in Pubmed: 17000631.

9. Di Tano G, De Maria R, Gonzini L, et al. IN-HF Outcome Investigators. The 30-day metric in acute heart failure revisited: data from IN-HF Outcome, an Italian nationwide cardiology registry. Eur J Heart Fail. 2015; 17(10): 1032-1041, doi: 10.1002/ejhf.290, indexed in Pubmed: 26018852.

10. De Sutter J, Pardaens S, Audenaert T, et al. Clinical characteristics and short-term outcome of patients admitted with heart failure in Belgium: results from the BIO-HF registry. Acta Cardiol. 2015; 70(4): 375-385, indexed in Pubmed: 26455238.

11. Panduranga P, Sulaiman K, Al-Zakwani I, et al. Clinical characteristics, management, and outcomes of acute heart failure patients: observations from the Gulf acute heart failure registry (Gulf CARE). Eur J Heart Fail. 2015; 17(4): 374-384, doi: 10.1002/ejhf.245, indexed in Pubmed: 25739882.

12. Ambrosy AP, Fonarow GC, Butler J, et al. The global health and economic burden of hospitalizations for heart failure: lessons learned from hospitalized heart failure registries. J Am Coll Cardiol. 2014; 63(12): 1123-1133, doi: 10.1016/j.jacc.2013.11.053, indexed in Pubmed: 24491689. 